\title{
Oligonucleotides as Hybridization Probes to Localize Phytoplasmas in Host Plants and Insect Vectors
}

\author{
D. R. Webb, R. G. Bonfiglioli, L. Carraro, R. Osler, and R. H. Symons
}

First, second, and fifth authors: Department of Plant Science, Waite Institute, University of Adelaide, Glen Osmond, SA 5064, Australia; and third and fourth authors: Dipartimento Biologia Applicata alla Difesa delle Piante, Università di Udine, I-33100, Udine, Italy. Accepted for publication 14 June 1999.

\begin{abstract}
Webb, D. R., Bonfiglioli, R. G., Carraro, L., Osler, R., and Symons, R H. 1999. Oligonucleotides as hybridization probes to localize phytoplasmas in host plants and insect vectors. Phytopathology 89:894-901.

Protocols have been developed using 20- to 24-mer oligodeoxynucleotides, originally designed as polymerase chain reaction primers, as hybridization probes for the nonradioactive detection of Italian clover phyllody (ICPh) phytoplasma in plant (Chrysanthemum carinatum) and leafhopper (Euscelidius variegatus) tissue. In situ hybridization of paraffin-embedded tissue sections was carried out using oligodeoxynucleotides $5^{\prime}$ end-labeled with either Cy5 fluorochrome, biotin, or digoxigenin. The Cy5-labeled

labeled probes were detected in both plant and insect tissue using a chromogenic alkaline phosphatase-nitro blue tetrazolium chloride/5-bromo4-chloro-3-indolyl-phosphate reaction. An enhancement of a signal was observed in plant tissue when a tyramide signal-amplification procedure was incorporated into the biotin or digoxigenin detection systems. The results obtained using these techniques with the ICPh phytoplasma system showed that they can provide a rapid means of confirming vector status in insects. Due to the potential ability of short, labeled, oligonucleotide probes to specifically distinguish between different phytoplasmas present in multiple infections, this technique should provide a powerful new tool for epidemiological and vector ecology studies.
\end{abstract} oligonucleotide probes that hybridized to phytoplasmas present in plant tissue were visualized by confocal microscopy. The biotin- and digoxigenin-
Additional keywords: fluorescent in situ hybridization, 16S ribosomal RNA.
Phytoplasmas (formerly mycoplasmalike organisms) are a large group of obligate intracellular parasites within the class Mollicutes and are associated with plant and insect diseases (29). They infect several hundred plant species and can cause serious damage to a wide variety of agricultural and ornamental crops (45). Phytoplasmas are specifically vectored by phloem-feeding insects such as leafhoppers, planthoppers, and psyllids, in which they multiply (9). In plant hosts, phytoplasmas are mostly restricted to, and multiply within, the phloem sieve tubes where they can migrate down to the roots and up to the top of the plant (36). Detailed molecular and biological studies of these organisms and their interactions with host plants and insects have been severely hampered by the inability to culture them in vitro. Consequently, many aspects of their biology remain poorly understood.

The relationships between phytoplasmas and insects are complex. Phytoplasmas exist within the host insect as intracellular parasites and are only transmissible to plants once they accumulate to high levels in the posterior acinar cells of the salivary gland (29). Antibody studies of vector insects have shown that, in addition to the acinar cells, phytoplasmas may be found within specialized cells of the midgut, in the haemolymph, and in the malphigian tubules (37).

It is known that, following the successful acquisition of a phytoplasma, an incubation, or latency, period is required before an insect is able to transmit the pathogen to plants $(29,51)$. During this latency period, it has been established that the phytoplasma must penetrate the epithelial cells of the midgut, where it undergoes replication within a vesicle. The phytoplasma must then cross the basement membrane barrier to enter the insects haemocoele, where it is considered to multiply in the circulating haemolymph.

Corresponding author: D. R. Webb; E-mail address: dwebb@waite.adelaide.edu.au

Publication no. P-1999-0826-01R

(C) 1999 The American Phytopathological Society
For the insect to become infectious, the phytoplasma must cross another membrane barrier to penetrate the posterior acinar cells of the salivary glands, where it undergoes further multiplication. The insect becomes infectious only when the phytoplasma has accumulated to such a level within the saliva that feeding introduces an inoculative dose to healthy plants. If the phytoplasma is able to pass into the haemolymph, but cannot enter specific cells of the salivary glands, the insect does not become infectious and hence is a "dead-end" host for that phytoplasma.

Thus, to show that an insect is a vector of a specific phytoplasma, it must be established that the phytoplasma has colonized the acinar cells of the salivary gland. The biological transmission studies typically used for vector confirmation are very time-consuming and slow (12). Further, there is currently no simple, rapid method to establish the vector status of an insect with respect to a specific phytoplasma, particularly if that insect is also hosting other phytoplasma strains.

Although polyclonal antibodies have previously been used successfully for generic in situ immunolocalization of phytoplasmas in green herbaceous plants and insects $(36-38,54)$, some monoclonal antibodies raised against one specific phytoplasma have been shown to cross-react with other strains $(14,26,28)$. In addition, some of the phytoplasma-specific membrane epitopes revealed by in situ immunochemistry might not be expressed over the whole phytoplasma life cycle, as has already been shown for other mollicutes (5). Moreover, antibodies to unculturable phytoplasmas are difficult and time-consuming to develop and often strongly crossreact with plant-derived antigens. Nucleic acid techniques, on the other hand, offer the potential for rapid and specific detection of phytoplasmas.

The polymerase chain reaction (PCR) has proven to be a powerful tool for phytoplasma detection in both plant and insect tissue $(12,23,39,50)$. However, significant problems arise when individual insects are tested by PCR for the presence of phytoplasmas. A typical insect-DNA extraction protocol $(24,44)$ involves grinding 
the whole insect in a buffer to extract the DNA. If the insect has recently fed on an infected plant, it is highly likely to contain the phytoplasma in its midgut and, therefore, is going to return a positive result in the PCR test, as has been reported by Vega et al. (58) for a nonhost insect. In addition, PCR analysis of DNA extracts cannot distinguish between dead-end hosts, insects within the infection latency period, and those insects that are vectors. Thus, PCR results derived from whole-insect extracts may lead to erroneous conclusions about the nature of the relationship between the insect and the pathogen.

On the basis of the discussion above, methods to specifically localize and distinguish between different phytoplasmas in situ are required for the development of studies aimed at determining the replication strategies and movement of phytoplasmas within their insect vectors. Although it is possible to isolate the salivary glands prior to PCR analysis for the presence of phytoplasma DNA (39), we consider it more informative to show the presence of phytoplasmas in situ by the use of specific hybridization probes.

In situ strain-specific detection of phytoplasmas is not, however, a simple process. The taxonomic classification of phytoplasmas is based mainly on the nucleic acid sequence of the $16 \mathrm{~S}$ ribosomal DNA (rDNA) $(25,33,53)$, which is so far the only stretch of DNA to be sequenced for nearly all known types of phytoplasmas. This sequence is widely conserved across most of the prokaryotic kingdom. A nucleic acid probe of 200 or so bases (as typically used for in situ hybridization) targeted against the 16S rDNA would be expected to hybridize to most prokaryotic organisms and could not, therefore, even be used as a general phytoplasma-specific probe. Fortunately, extensive studies on the 16S rDNA of phytoplasmas have identified variable regions and permitted the construction of group-specific $(31,40,41,56)$ and strain-specific $(21,40,42)$ oligonucleotides for PCR.

The difficulties associated with traditional in situ probes led us to develop the use of short (20- to 24-mer) oligonucleotides, $5^{\prime}$ endlabeled with a nonradioactive reporter molecule, as strain-specific probes for in situ hybridization reactions. Although the use of short sequences requires the careful optimization of the hybridization reaction conditions, oligonucleotides have been successfully utilized as strain-specific probes in the dot blot hybridization of PCRamplified phytoplasma DNA $(22,43)$ and by our collaborators at the Institut National de la Recherche Agronomique (INRA), Dijon Cedex, France, in the localization of phytoplasmas in plant cells using electron microscopy (34). Furthermore, fluorescently labeled 16S rRNA-targeted oligonucleotide probes have been successfully used for the detection of individual species in bacterial biofilms using confocal laser scanning microscopy (3). Thus, the use of short, nonradioactively labeled oligonucleotides for strain-specific in situ hybridization of phytoplasmas in both plant and insect tissue was considered to be both appropriate and feasible.

Fluorescent reporter systems commonly used for in situ hybridization in conjunction with oligonucleotide probes (2) have been successfully adapted for the detection of viroids in plant tissue (8). However, they are likely to be unsuitable for phytoplasma detection in insects, because the intense broadband autofluorescence of the insect alimentary tract (35) may mask specific signals. For this and other reasons, we elected to develop the alkaline phosphatase (AP)-nitro blue tetrazolium chloride/5-bromo-4-chloro-3-indolylphosphate (NBT/BCIP) system for our insect studies. Recent studies have shown that digoxigenin-labeled oligonucleotides, detected with antibody-AP conjugates and using NBT/BCIP as the substrate, produce results directly comparable to immunofluorescent detection when probing for bacterial 23S rRNA in plants (59). In addition, the AP-NBT/BCIP detection system requires only basic equipment and is ideally suited to whole-insect studies. It also provides an additional advantage in that it is amenable to posthybridization amplification, using the AP-anti-AP system (19) and the more recently introduced biotinyl-tyramide catalyzed reporter deposition system $(7,20)$.

\section{MATERIALS AND METHODS}

Insects and phytoplasmas. The Italian clover phyllody (ICPh) phytoplasma was transmitted, using dodder (Cuscuta campestris Younk), from the original host Chrysanthemum leucanthemum L. to periwinkle (Catharanthus roseus G. Don) and then from periwinkle to Chrysanthemum carinatum L. following the procedures described by Bennett (6). Leafhoppers (Euscelidius variegatus Kirschbaum) were then used to transmit the phytoplasma to other $C$. carinatum plants that were maintained in a greenhouse prior to sampling. Leafhoppers (E. variegatus) were kept on C. carinatum infected with ICPh phytoplasma for 3 days, to ensure acquisition, before being maintained on healthy barley plants for 20 or 30 days prior to sampling.

Insect and plant specimens were maintained and prepared within the Dipartimento Biologia Applicata alla Difesa delle Piante, Università di Udine, before being shipped to the Department of Plant Science, Waite Institute, University of Adelaide, for the in situ hybridization studies described here.

Sample preparation. Samples of infected and uninfected E. variegatus and C. carinatum were fixed in cold PIPES (1,4-piperidinediethanesulfonic acid) buffer $(50 \mathrm{mM}, \mathrm{pH} 7.8$, containing $4 \%$ paraformaldehyde and $0.25 \%$ glutaraldehyde) for a few hours and then washed three times in cold PIPES buffer. Samples were then dehydrated to absolute ethanol (in six steps from 25\%). After two changes of absolute ethanol, samples were cleared in xylene (three changes) before being transferred to liquefied $\left(60^{\circ} \mathrm{C}\right)$ Paraplast (Oxford Labware, St Louis). Final Paraplast infiltration was aided by the application of a gentle $(-0.2$ to -0.4 bar) vacuum. Infiltrated samples were then oriented, and three to five individual specimens were embedded in each wax block. To minimize handling damage and losses, samples were contained within Perk Tissue Cassettes (Filtertek, Hebron, IL) during all stages of fixation and infiltration.

Oligodeoxynucleotide probes. Oligodeoxynucleotides that were designed as PCR primers for the amplification of specific phytoplasma DNA were used as hybridization probes. To maximize sensitivity, (-)-sense oligonucleotides capable of hybridizing to both the genomic DNA and rRNA were used throughout. These were 5' end-labeled after synthesis with digoxigenin, biotin (Boehringer Mannheim Biochemicals, Indianapolis, IN), or Cy5 flurochrome (Amersham Life Sciences, Piscataway, NJ). All reactions and procedures were performed in accordance with the recommendations of model 370 DNA sequencer user Bulletin 11 (Applied Biosystems, Foster City, CA) and the appropriate product data sheets. In summary, $5^{\prime}$ end labeling was achieved by attaching an aminohexyl linker (Aminolink 2; Applied Biosystems) to the $5^{\prime}$ end of the oligonucleotide at the final stage of chemical synthesis on an ABI 392 nucleic acid synthesizer (Applied Biosystems). After cleavage and deprotection at $55^{\circ} \mathrm{C}$ overnight, an $N$-hydroxysuccinimide ester derivative of digoxigenin, biotin, or Cy5 fluorochrome was coupled to the oligonucleotide at the free $5^{\prime}$ amino group through the aminohexyl linker. The derivatized oligonucleotides were then purified by high-performance liquid chromatography following the general procedure of Smith et al. (57).

We selected oligonucleotide probes CPc727, CPc1123, and CPc1240 by comparative sequence analysis on the basis of their complementarity to regions within the ICPh phytoplasma $16 \mathrm{~S}$ rDNA (GenBank no. X77482) (21), which have low similarity to the rDNA sequences of other phytoplasmas. Two other oligonucleotides already available in our laboratory, Stol(-) with specificity for stolburtype phytoplasmas (complementary to fStol of Maixner et al. [41]) and $\mathrm{PD}(-)$ with specificity for pear decline phytoplasmas (the rPDS of Lorenz et al. [40]), were used to verify that no nonspecific binding of oligonucleotides was occurring and that the hybridization conditions precluded cross-hybridization to these unrelated phytoplasmas. The ICPh phytoplasma is a member of the $\mathrm{X}$ group of phytoplasmas (21); its 16S rDNA sequence differs from pear decline phytoplasma (a member of the apple proliferation group [33]) by 
$12 \%$ and from the Stolbur group phytoplasmas by approximately $13 \%$. Sequences of the oligonucleotides and their phytoplasma specificities are shown in Table 1.

In situ hybridization. Sections of wax-embedded E. variegatus and $C$. carinatum of 8 to $10 \mu \mathrm{m}$ in thickness were cut from the wax blocks, floated on water, and mounted on glass slides derivatized with $\gamma$-methacryloxypropyl-trimethoxy-silane (Sigma Chemical Co., St Louis) and poly-L-lysine (17). The slides were air-dried, dewaxed by immersion in xylene for $5 \mathrm{~min}$, and the xylene was then removed by immersion in $100 \%$ ethanol for two periods of 5 min each. The slides were again air-dried and a silane solution $(0.2 \%$ $\gamma$-methacryloxypropyl-trimethoxy-silane and $0.2 \%$ acetic acid in ethanol) (17) was applied. After air drying, the slides were washed twice in $100 \%$ ethanol for $2 \mathrm{~min}$ and again air-dried. Sections were then digested with Proteinase $\mathrm{K}(1 \mathrm{mg} / \mathrm{ml}$ in $50 \mathrm{mM}$ Tris$\mathrm{HCl}, 5 \mathrm{mM}$ EDTA, and $0.02 \%$ sodium dodecyl sulfate, $\mathrm{pH} 7.6$ ) for 5 to $20 \mathrm{~min}$ at room temperature. The slides were then washed twice ( $5 \mathrm{~min}$ each) in $50 \mathrm{mM}$ Tris- $\mathrm{HCl}, 5 \mathrm{mM}$ EDTA ( $\mathrm{pH} 7.5$ ), and twice briefly in water, air-dried, and then subjected to in situ hybridization.

In situ hybridization was done by applying $40 \mu \mathrm{l}$ of in situ hybridization buffer (40 $\mathrm{mM}$ PIPES, $0.1 \%$ polyvinylpyrrolidine $[10 \mathrm{~K}]$, $0.1 \%$ Ficoll 4000 , and $140 \mathrm{mM} \mathrm{NaCl}, \mathrm{pH} 7.8$.) containing a total of $200 \mathrm{ng}$ of probe per ml, either individually or as a mixed oligonucleotide cocktail, onto the slides. A coverslip was applied and sealed with rubber gum. Sealed slides were incubated for a minimum of $4 \mathrm{~h}$ at $50^{\circ} \mathrm{C}$. Coverslips were removed and the slides washed in $2 \times \mathrm{SSC}(1 \times \mathrm{SSC}=150 \mathrm{mM} \mathrm{NaCl}$ and $15 \mathrm{mM}$ tri-sodium citrate, $\mathrm{pH} 7.0$ ) and then $1 \times \mathrm{SSC}$ for $30 \mathrm{~min}$, each at $42^{\circ} \mathrm{C}$, followed by washing in $0.2 \times \mathrm{SSC}$ at room temperature for $30 \mathrm{~min}$ to remove any improperly hybridized or nonspecifically hybridized probe.

Detection and visualization of hybridized probes. Visualization of hybridized Cy5-labeled probes. The fluorescence data were collected on a Biorad MRC 1000 confocal laser scanning microscope (Bio-Rad Laboratories, Hercules, CA). Cy5 is a far-red emitting fluorochrome. It was used because the fixed plant material examined had high levels of autofluorescence in the green and red emission channels. In the far-red channel, no autofluorescence was observed. Following hybridization and washing, the slides were washed in phosphate-buffered saline (PBS; $140 \mathrm{mM} \mathrm{NaCl}, 10 \mathrm{mM}$ $\mathrm{Na}_{2} \mathrm{HPO}_{4}, 2.5 \mathrm{mM} \mathrm{KCl}$, and $1.75 \mathrm{mM} \mathrm{KH} \mathrm{PO}_{4}, \mathrm{pH}$ 7.4) for $5 \mathrm{~min}$ prior to mounting in $70 \%$ glycerol $+30 \%$ PBS. To show structural detail, tissue autofluorescence was collected in the green channel using 488-nm excitation and a 525-nm narrow-band pass-emission filter. The far-red fluorescence signal from the Cy5-labeled probes was collected using 647-nm excitation and a 670-nm-long passemission filter.

Detection of hybridized biotin- and digoxigenin-labeled probes. Following hybridization and washing, the detection of the hybridized probes was performed in either a one-step procedure by incubation with AP-conjugated streptavidin or anti-digoxigenin monoclonal antibodies (Boehringer Mannheim Biochemicals) or a multistep, catalyzed reporter deposition-signal amplification $(1,7)$ followed by incubation with AP-conjugated streptavidin. The bound AP was then visualized by enzyme-catalyzed chromogen deposition, based upon the method of McGadey (46), as described below. Incuba- tions and washes were done at room temperature and washes were for $5 \mathrm{~min}$, unless otherwise noted.

Single-step detection of hybridized biotin- and digoxigenin-labeled probes. Following hybridization and washing, slides not undergoing signal amplification were washed twice in Tris-buffered saline (TBS; $100 \mathrm{mM}$ Tris and $150 \mathrm{mM} \mathrm{NaCl}, \mathrm{pH} \mathrm{7.5)}$ and then blocked for $30 \mathrm{~min}$ with TBS $+1 \%$ bovine serum albumen (BSA)fraction $\mathrm{V}$ prior to a 30 -min incubation with either streptavidin-AP or anti-digoxigenin-AP at Boehringer Mannheim's recommended dilutions in TBS $+1 \%$ BSA. Unbound streptavidin-AP or antidigoxigenin-AP was removed from the tissue by two washes in TBS, after which slides were subjected to the AP-NBT/BCIP chromogenic reaction described below.

Signal amplification of biotin- and digoxigenin-labeled probes by catalyzed reporter deposition. In catalyzed reporter deposition (7), horseradish peroxidase catalyzes the activation of conjugated phenolic compounds (e.g., biotinyl-tyramide, in our case), resulting in the covalent binding of the intermediate radicals to electronrich moieties in the protein molecules present at the site of reaction. Signal amplification was performed using the Renaissance TSA (tyramide signal amplification)-Indirect kit (NEN Life Science Products, Boston, MA) using a 10-min amplification step and in accordance with the manufacturer's protocol.

Following hybridization and washing, all slides were washed three times in TBS $+0.05 \%$ Tween 20 (TBST) before being blocked with TBS $+0.5 \%$ blocking reagent (TNB) for $30 \mathrm{~min}$ at $37^{\circ} \mathrm{C}$ (blocking reagent was supplied in the Renaissance TSA-Indirect kit). Tissue sections hybridized with biotin-labeled oligonucleotide probes were then reacted for 30 min with streptavidin-conjugated horseradish peroxidase (supplied in the kit) diluted 1:100 in TNB, whereas sections hybridized with digoxigenin-labeled oligonucleotide probes were then incubated for $30 \mathrm{~min}$ with anti-digoxigenin antibodies conjugated to horseradish peroxidase (Boehringer Mannheim Biochemicals) diluted 1:100 in TNB. All slides were then washed three times in TBST. For amplification, tissue sections were incubated in biotinyl-tyramide working solution (supplied in the kit) for $10 \mathrm{~min}$. Following amplification, the slides were washed once in TBST and then washed twice in TBS. Slides were then blocked for 30 min with TBS $+1 \%$ BSA-fraction $\mathrm{V}$ prior to a 30-min incubation with streptavidin-AP at Boehringer Mannheim's recommended dilutions in TBS $+1 \%$ BSA. Unbound streptavidin-AP was removed from the tissue by two washes in TBS, after which, slides were subjected to the AP-NBT/BCIP chromogenic reaction.

Chromogenic AP-NBT/BCIP reaction. AP-catalyzed chromogen deposition was based upon the original method of McGadey (46). Slides were first washed twice in AP buffer $\left(50 \mathrm{mM} \mathrm{MgCl}_{2}, 5 \mathrm{mM}\right.$ $\mathrm{NaN}_{3}, 100 \mathrm{mM} \mathrm{NaCl}$, and $100 \mathrm{mM}$ Tris, $\mathrm{pH}$ 9.5) and then were incubated in AP buffer containing NBT $(330 \mu \mathrm{g} / \mathrm{ml})$ and BCIP $(150 \mu \mathrm{g} / \mathrm{ml})$ for between 8 and $15 \mathrm{~min}$. The color reaction was stopped by washing the slides briefly with water, followed by two washes in $50 \mathrm{mM}$ Tris and $1 \mathrm{mM}$ EDTA ( $\mathrm{pH} 7.0)$. Tissue sections were then counterstained with the recommended (16) Jensens neutral red ( $100 \mathrm{mg}$ of neutral red powder, $200 \mu \mathrm{l}$ of $1 \%$ acetic acid, and $100 \mathrm{ml}$ of $\mathrm{H}_{2} \mathrm{O}$ ) for $45 \mathrm{~s}$, washed three times for $1 \mathrm{~min}$ in water, and then air-dried prior to mounting in D.P.X. mountant (Fluka Chemical Corp., Milwaukee, WI) and microscopic observation. Levamisole

TABLE 1. Sequences and target sites of the phytoplasma-specific oligonucleotides used as hybridization probes

\begin{tabular}{|c|c|c|c|c|}
\hline Probe & Phytoplasma specificity & Target site ${ }^{a}$ & Target residues & Oligonucleotide sequence of probe \\
\hline СРc727 & Italian clover phyllody $\mathrm{b}$ & $16 \mathrm{~S}$ & $727-746^{\mathrm{b}}$ & 5'-GTGCCTCAGCGTCAGTAAAG-3' \\
\hline CPc1123 & Italian clover phyllody ${ }^{b}$ & $16 \mathrm{~S}$ & $1,123-1,142^{b}$ & 5'-TTTCATTGGCAGTCTCGTTA-3' \\
\hline CPc1240 & Italian clover phyllody ${ }^{b}$ & $16 \mathrm{~S}$ & $1,240-1,263^{\mathrm{b}}$ & 5'-TTTGTGAGATTGGCTAAGAACTCG-3' \\
\hline $\mathrm{PD}(-)$ & Pear decline ${ }^{\mathrm{d}}$ & SR & $71-90^{\mathrm{d}}$ & $5^{\prime}$-CCCGGCCATTATTAATTTTA-3' \\
\hline
\end{tabular}

a $16 \mathrm{~S}=16 \mathrm{~S}$ ribosomal DNA, and $\mathrm{SR}=16 \mathrm{~S}$ to $23 \mathrm{~S}$ ribosomal DNA spacer region.

${ }^{\mathrm{b}}$ Firrao et al. (21), GenBank no. X77482.

c Maixner et al. (41), GenBank no. X76247.

${ }^{\mathrm{d}}$ Lorenz et al. (40), GenBank no. U54989. 
was not included in AP buffers to inhibit endogenous AP (49), because no endogenous AP activity was found in control sections.

Controls for hybridization and enzymatic detection reactions. Control experiments included the omission of the probe, omission of the antibody-enzyme conjugate, and the use of healthy plant and insect material. Omission of the probe was used to test for the presence of endogenous digoxigenin or biotin as well as any other false signals. Omission of the antibody-enzyme conjugate tests specifically for the presence of endogenous phosphatases or peroxidase.

\section{RESULTS}

Prehybridization treatment of tissue sections. We found that prehybridization digestion of tissue sections with Proteinase K $(1 \mathrm{mg} / \mathrm{ml})$ for 10 min was optimal, because this resulted in the most intense hybridization signal on infected tissue. Digestion with Proteinase $\mathrm{K}$ for either 5 or $20 \mathrm{~min}$ resulted in only a faint hybridization signal on infected tissue, indicating that these times represent underdigestion and overdigestion, respectively. In contrast, no hybridization signal was seen in any of our samples if tissue sections were digested prior to hybridization with $1 \mathrm{mg}$ of pepsin per $\mathrm{ml}(50 \mathrm{mM}$ glycine, $\mathrm{pH} 3.0$ ) for $2,5,10,15,20$, or $30 \mathrm{~min}$. The use of derivatized glass slides plus silane solution was essential to ensure adhesion of the insect tissue to the slides.

In situ hybridization of $\boldsymbol{C}$. carinatum tissue using fluorescent Cy5-labeled oligonucleotide probes. Cy5 is a far-red emitting fluorochrome that we found to be an excellent reporter molecule for use in plant material (8). The fluorescence signal of hybridized Cy5-labeled oligonucleotide probes could be readily detected in the phloem tissue of all sections obtained from the three ICPh- infected chrysanthemum plants examined. All ICPh-specific probes showed a similar localization of a signal within the phloem tissue, although the CPc727 probe (data not shown) was less intense than the CPc1240 probe (Fig. 1B) or the CPc1123 probe (Fig. 1D) on some samples. No signal was ever observed in uninfected tissue hybridized with ICPh-specific oligonucleotides (Fig. 1A), nor was any signal observed in ICPh-infected tissue hybridized with the PD(-) pear decline phytoplasma-specific oligonucleotide (Fig. 1C).

Detection of hybridized digoxigenin- and biotin-labeled probes in leafhopper tissue using the AP-NBT/BCIP system. Using ICPh-specific digoxigenin- or biotin-labeled oligonucleotide probes, we could detect a hybridization signal in the midgut of ICPh-infected E. variegatus leafhoppers at both 20 (Fig. 2F) and 30 days (data not shown) postacquisition, with a more intense signal at 20 days. In contrast, a hybridization signal was detected in the salivary glands of only 1 of the 32 infected leafhoppers examined at 20 days postacquisition and, in this insect, the hybridization signal was very faint (data not shown). However, by 30 days postacquisition, a strong hybridization signal was detected in the posterior lobes of the salivary glands of all 27 infected leafhoppers examined (Fig. 2B and D), indicating that, at 30 days postacquisition, these leafhoppers were potentially infectious for ICPh phytoplasma. A hybridization signal was also occasionally detected in the fat bodies of infected leafhoppers at both 20 and 30 days postacquisition (data not shown).

Hybridization signal intensity was the same regardless of whether a mixed cocktail, containing three ICPh-specific oligonucleotides (CPc727, CPc1123, and CPc1240) (Fig. 2B), or a single ICPh-specific oligonucleotide (CPc1123) (Fig. 2D) was used as the probe. Signal intensity was also the same for biotin- and digoxigenin-labeled oligonucleotides (Fig. 2D and F, respectively). No hybrid-
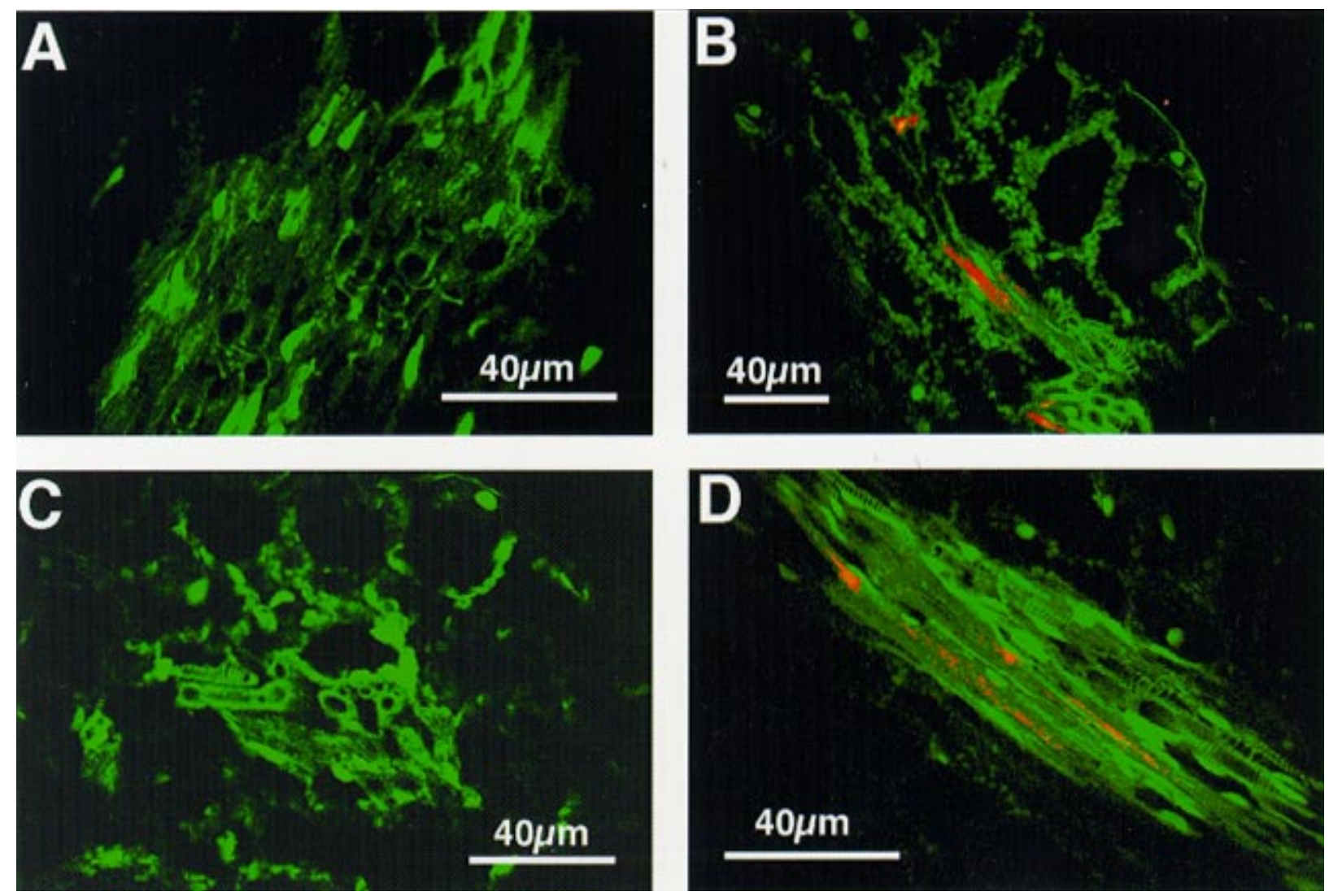

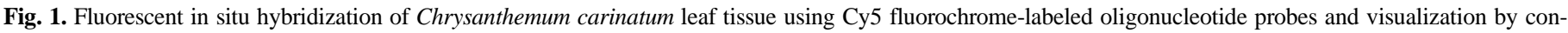

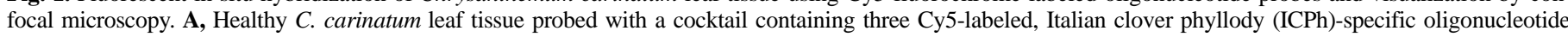

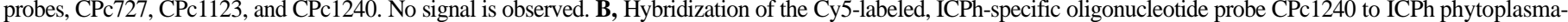

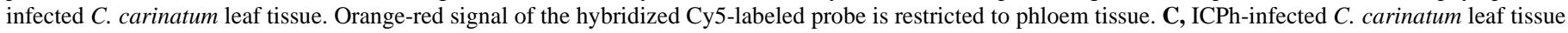

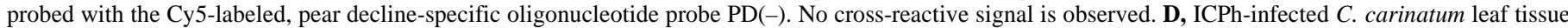
probed with the Cy5-labeled, ICPh-specific oligonucleotide probe CPc1123. As in $\mathbf{B}$, the orange-red CY5 fluorochrome signal is restricted to phloem tissue. 
ization signal was observed with any probe or in any tissue of our uninfected leafhopper controls (Fig. 2A and E). When ICPh-infected $E$. variegatus leafhopper tissue (30 day postacquisition) was hybridized with the stolbur group-specific Stol(-) probe under the conditions described previously, no hybridization signal was detected (Fig. 2C). However, if the hybridization temperature was lowered from 50 to $48^{\circ} \mathrm{C}$ to provide less stringent conditions, a weak cross-hybridization signal was observed in the salivary glands of the leafhoppers (data not shown).

Posthybridization tyramide amplification of a signal from hybridized digoxigenin- and biotin-labeled probes. In ICPhinfected $C$. carinatum leaf tissue, the addition of posthybridization tyramide signal amplification (Renaissance TSA-Indirect kit) increased the signal intensity of both biotin- and digoxigenin-labeled probes (Fig. 3C and D, respectively) as compared with an unamplified sample (Fig. 3B). This amplification did not produce any nonspecific background signals from healthy leaf tissue (Fig. 3A) or result in any detectable loss of resolution. Hybridization signals were restricted to the phloem tissue in both amplified and unamplified samples, and the localization within the phloem was the same as that obtained with the Cy5-labeled probes (Fig. 1B and D).

In contrast, in ICPh-infected $E$. variegatus leafhopper tissue, the addition of a posthybridization tyramide signal-amplification procedure was of only limited benefit. In optimally digested leafhopper tissue (Proteinase $\mathrm{K}, 1 \mathrm{mg} / \mathrm{ml}$ for $10 \mathrm{~min}$ ), hybridized with biotinor digoxigenin-labeled ICPh-specific oligonucleotide probes, the tyramide signal-amplification procedure did not produce any detectable increase in hybridization signal as compared with unam-
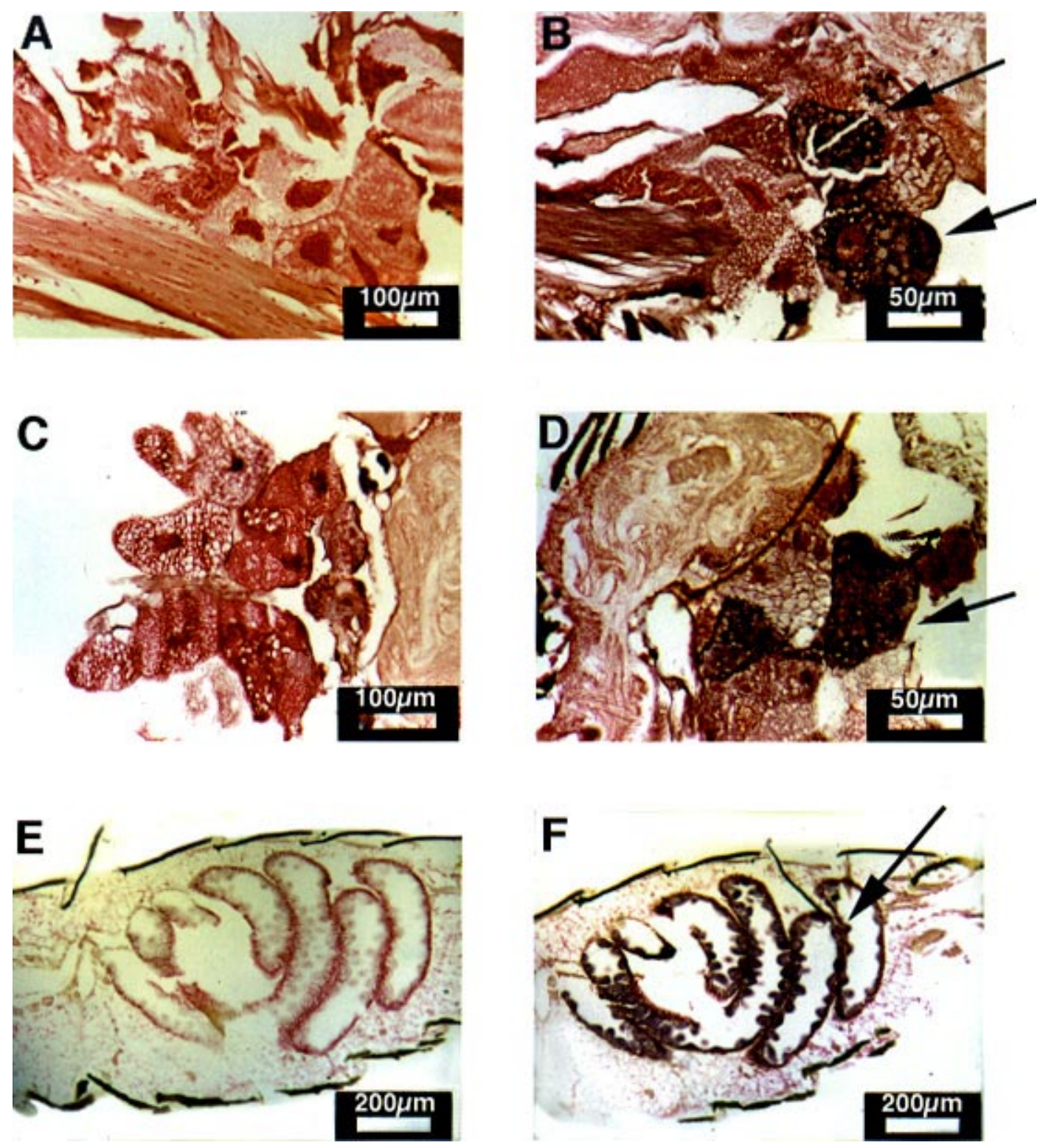

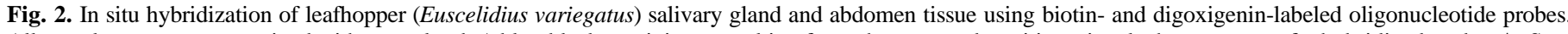

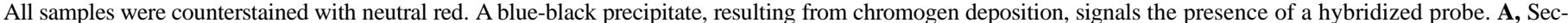

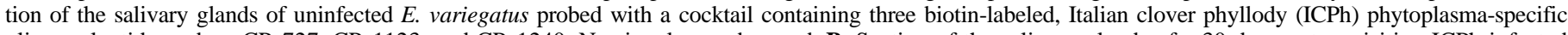

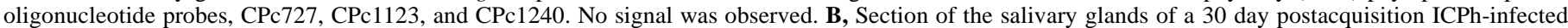

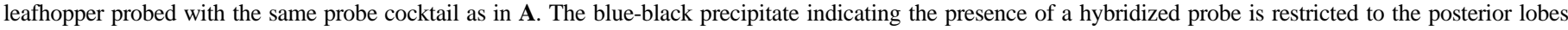

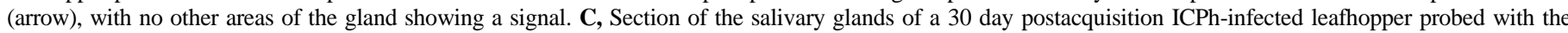

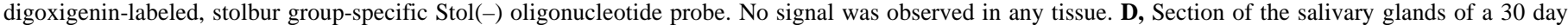

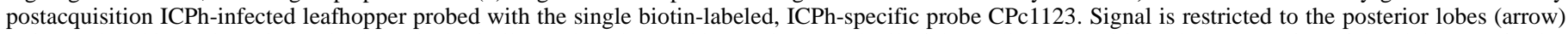

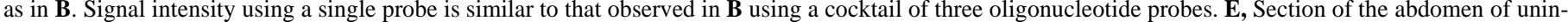

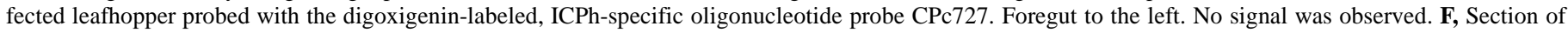

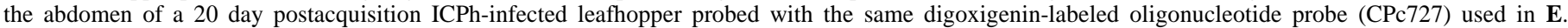
Foregut to the left. Intense signal in the midgut is indicated with an arrow. 
plified samples. In underdigested (Proteinase $\mathrm{K}, 1 \mathrm{mg} / \mathrm{ml}$ for $5 \mathrm{~min}$ ) and overdigested (Proteinase $\mathrm{K}, 1 \mathrm{mg} / \mathrm{ml}$ for $20 \mathrm{~min}$ ) leafhopper tissue, enhancement of a signal was observed in the salivary glands and midgut as compared with unamplified samples (data not shown). However, the tyramide signal-amplification procedure also resulted in a background signal in the muscle tissue of all of the 36 infected and 6 uninfected leafhoppers examined. This background reduced the signal-to-noise ratio and, hence, the overall benefit of the amplification (data not shown). No difference in signal intensity or nonspecific background was detected between tyramide signalamplified biotin- and digoxigenin-labeled oligonucleotides (compare Fig. 3C and D), indicating that the tyramide signal-amplification procedure was equally effective on both probe types.

In summary, we found the tyramide signal-amplification procedure to be useful during the optimization of the proteolytic digestion step, because it produced a signal in all samples over a wide range of protease treatments. Once reaction conditions were optimized, it was only of benefit on plant tissue.

\section{DISCUSSION}

The results obtained in this study clearly show that short, nonradioactively labeled oligonucleotides, which we designed as strainspecific PCR primers, also allow in situ detection of phytoplasmas in both insect and plant tissue. As far as we know, this is the first successful use of oligonucleotide probes for in situ detection of phytoplasmas in both host plants and vectors. The use of PCR primer sequences as hybridization probes has significant advantages over traditional in situ probes. Major advantages, in addition to their high selectivity, are that sequences for PCR primers are available for most known pathogens, and existing primers can be easily $3^{\prime}$ end-labeled using terminal deoxynucleotidyl transferase or $5^{\prime}$ endlabeled using T4 polynucleotide kinase $(47,48)$ or reporter molecules can be incorporated during chemical synthesis at low cost.

Like Ehrlein et al. (18), who used digoxigenin-labeled RNA probes and the AP-NBT/BCIP detection system on paraffin-embedded aldehyde-fixed pituitary tissue, we found that optimization of the prehybridization proteolytic digestion was crucial for obtaining satisfactory hybridization signals. However, when the tyramide signal-amplification procedure was used, we found that satisfactory signals can be obtained over a range (5 to $20 \mathrm{~min}$ ) of protease digestion times. It has previously been reported that tyramide signal amplification is useful for increasing a weak immunostaining signal caused by suboptimal tissue fixation (27). These two observations indicate that tyramide signal amplification is most useful in situations in which the number of reporter molecules is limiting. Low reporter molecule numbers may be due to low target numbers or a result of compromises in tissue preparation that restrict probe access, target availability, or both. Our finding that tyramide-amplified probes in chrysanthemum tissue showed a more intense
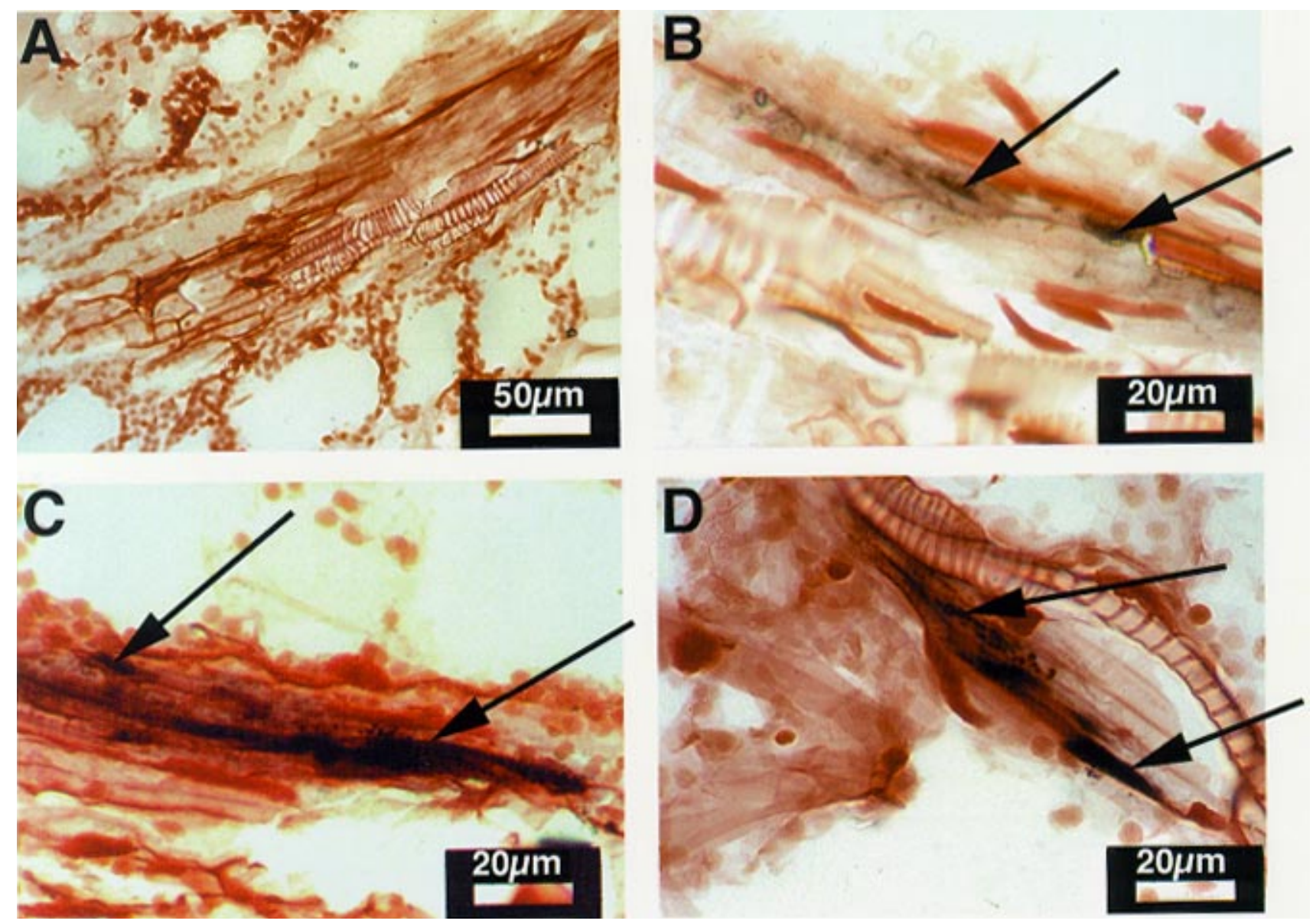

Fig. 3. In situ hybridization of Chrysanthemum carinatum leaf tissue using biotin- and digoxigenin-labeled oligonucleotide probes coupled to posthybridization tyramide signal amplification. All samples were counterstained with neutral red. A, Uninfected $C$. carinatum leaf tissue probed with a cocktail containing three biotin-labeled, Italian clover phyllody (ICPh) phytoplasma-specific oligonucleotide probes, CPc727, CPc1123, and CPc1240. Tyramide signal amplification applied. No signal was detected. B, Section of ICPh-infected C. carinatum leaf tissue probed with the same oligonucleotide cocktail as in A but without tyramide signal amplification. The blue-black precipitate (arrow) resulting from chromogen deposition, indicating the presence of a hybridized probe, is restricted to phloem tissue, as for the fluorescence signal in Figure 1B and D. C, Section of ICPh-infected C. carinatum leaf tissue probed with the same ICPhspecific, biotin-labeled, oligonucleotide cocktail as in A and $\mathbf{B}$. Tyramide signal amplification applied. The blue-black signal (arrow) is still restricted to phloem tissue but is of a higher intensity than the unamplified sample (B). D, Section of ICPh-infected C. carinatum leaf tissue probed with the single digoxigeninlabeled ICPh-specific oligonucleotide probe CPc727. Tyramide signal amplification applied. The blue-black signal (arrow) is largely restricted to phloem tissue and is of a similar intensity to that in $\mathbf{C}$. 
signal than did unamplified probes may be a result of low titers of phytoplasma in the plant tissue, a situation that has been reported in other phytoplasma systems (15).

The findings of this study using oligonucleotide probes are in strong agreement with previous electron microscopic $(52,55)$ and immunochemical $(35,37,38)$ phytoplasma localization studies in leafhoppers. Significantly, our findings agree not only with established tissue localization but also in respect to the time frames of acquisition and latency for the ICPh phytoplasma in leafhoppers, previously established by Carraro et al. (11). Similarly, our results in chrysanthemum are consistent with the electron microscopy studies of the ICPh phytoplasma in periwinkles (Catharanthus roseus) and dodder (Cuscuta campestris), in that we also found the phytoplasma restricted to phloem tissue (13). Such correlation between our findings and previously established physical, immunochemical, and biological data confirm the high specificity of the labeled oligonucleotide procedure we developed in this work. Our procedure is clearly suitable for use as a rapid means of confirming the true vector status of insects and has many other potential applications in the study of insect-vectored disease.

Short oligonucleotide-based in situ hybridization techniques, such as the one we developed for phytoplasmas, are capable of discriminating between targets with high sequence similarity, as also shown by Brunning and Durrant (10) for messenger RNA (mRNA). Using hapten-labeled oligonucleotides and an AP-NBT/BCIP detection system, they showed that a 24-mer oligonucleotide probe recognized its rat pituitary mRNA target. However, when a single base change was made at position 13 , the target was not recognized. This high level of probe specificity has important implications for the study of organisms like phytoplasmas, in which traditional in situ hybridization and immunochemical detection techniques are incapable of differentiating individual strains.

A similar specificity to that obtained by Brunning and Durrant (10) should be achievable in our system, enabling the discrimination of a specific phytoplasma in a background of one or more related phytoplasmas. This would enable the investigation of many new aspects of phytoplasma biology and ecology as well as aspects of vector-host biology. It should, for example, be possible to investigate in situ the phytoplasma-phytoplasma interactions involved in cross-protection, both in plants and insects (4). It may also be feasible to study the phytoplasma interactions in those diseases of perennial fruit crops in which dual or multiple infection is required for symptom expression (30).

Other potential applications include examining the possibility of sexual reproduction and interstrain crosses in multiple infected hosts. It should also be possible to examine the ability of insect vectors to carry and transmit multiple phytoplasmas, information that is required for interpreting and testing speciation and ecological models like the one recently proposed by Lee et al. (32).

Overall, our results demonstrate that in situ hybridization using short, labeled, oligonucleotide probes is a powerful, sensitive, and specific tool. We have shown that it is well suited to applications in both insect and plant material and that it can be used as a reliable, rapid means of confirming vector status in insects. In addition, short, labeled, oligonucleotide probes have the potential ability to distinguish, in situ, between targets with high sequence similarity. Consequently, this technique offers enormous potential for investigating many of the vexing questions concerning the biology, ecology, and epidemiology not only of phytoplasmas, but also of many other insect-vectored pathogens.

\section{ACKNOWLEDGMENTS}

This work was supported by the Australian Research Council Special Research Centre for Basic and Applied Plant Molecular Biology and a travel grant from the Faculty of Agricultural and Natural Resource Sciences, University of Adelaide. We thank N. Shirley and colleagues at the Nucleic Acid and Protein Chemistry Unit, University of Adelaide, for synthesis, labeling, and purification of the oligodeoxynucleotides; and G. Firrao, N. Loi, and all our other friends at the Università di Udine, without whose interest and assistance this project would not have been possible.

\section{LITERATURE CITED}

1. Adams, J. C. 1992. Biotin amplification of biotin and horseradish peroxidase signals in histochemical stains. J. Histochem. Cytochem. 40: 1457-1463.

2. Amann, R. I., Krumholz, L., and Stahl, D. A. 1990. Fluorescent-oligonucleotide probing of whole cells for determinative, phylogenetic, and environmental studies in microbiology. J. Bacteriol. 172:762-770.

3. Amann, R. I., Ludwig, W., and Schleifer, K. H. 1995. Phylogenetic identification and in situ detection of individual microbial cells without cultivation. Microbiol. Rev. 59:143-169.

4. Banttari, E. E., and Zeyen, R. J. 1979. Interactions of mycoplasmalike organisms and viruses in dually infected leafhoppers, planthoppers and plants. Pages 327-347 in: Leafhopper Vectors and Plant Disease Agents. K. Maramorosch and K. F. Harris, eds. Academic Press, New York.

5. Behrens, A., Heller, M., Kirchhoff, H., Yogev, D., and Rosengarten, R. 1994. A family of phase- and size-variant membrane surface lipoprotein antigens (VSPS) of Mycoplasma bovis. Infect. Immun. 62:5075-5084.

6. Bennett, C. W. 1967. Plant viruses: Transmission by dodder. Pages 393401 in: Methods in Virology, Vol. 1. K. Maramorosch and H. Koprowski, eds. Academic Press, New York.

7. Bobrow, M. N., Harris, T. D., Shaughnessy, K. J., and Litt, G. J. 1989. Catalyzed reporter deposition, a novel method of signal amplification. Application to immunoassays. J. Immunol. Methods 125:279-285.

8. Bonfiglioli, R. G., Webb, D. R., and Symons, R. H. 1996. Tissue and intra-cellular distribution of coconut cadang cadang viroid and citrus exocortis viroid determined by in situ hybridization and confocal laser scanning and transmission electron microscopy. Plant J. 9:457-465.

9. Boudon-Padieu, E., Larrue, J., and Caudwell, A. 1989. ELISA and dotblot detection of Flavescence Doree-MLO in individual leafhopper vectors during latency and inoculative state. Curr. Microbiol. 19:357-364.

10. Brunning, S., and Durrant, I. 1996. Single base mismatch analysis in nonradioactive in situ hybridization. TIG 12:392-393.

11. Carraro, L., Loi, N., Gregoris, A., Ermacora, P., and Osler, R. 1996. Studies on the transmission of a phytoplasma from Chrysanthemum leucanthemum L. by the leafhopper Euscelidius variegatus Kbm. IOM Lett. 4:127-128.

12. Carraro, L., Loi, N., Kuszala, C., Clair, D., Boudon-Padieu, E., and Refatti, E. 1994. On the ability-inability of Scaphoideus titanus Ball. to transmit different grapevine yellows agents. Vitis 33:231-234.

13. Carraro, L., Osler, R., Loi, N., and Favali, M. A. 1991. Transmission characteristics of the clover phyllody agent by dodder. J. Phytopathol. 133:15-22.

14. Chen, K. H., Credi, R., Loi, N., Maixner, M., and Chen, T. A. 1994. Identification and grouping of mycoplasmalike organisms associated with grapevine yellows and clover phyllody diseases based on immunological and molecular analyses. Appl. Environ. Microbiol. 60:1905-1913.

15. Chen, K. H., Guo, J. R., Wu, X. Y., Loi, N., Carraro, L., Guo, Y. H., Chen, Y. D., Osler, R., Pearson, R., and Chen, T. A. 1993. Comparison of monoclonal antibodies, DNA probes, and PCR for detection of the grapevine yellows disease agent. Phytopathology 83:915-922.

16. De Jong, A. S. H., Van Kessel-Van Vark, M., and Raap, A. K. 1985. Sensitivity of various visualization methods for peroxidase and alkaline phosphatase activity in immunoenzyme histochemistry. Histochem. J. 17:1119-1130.

17. Dyanov, H. M., and Dzitoeva, S. G. 1995. Method for attachment of microscopic preparations on glass for in situ hybridization, PRINS and in situ PCR studies. Biotechniques 18:822-826.

18. Ehrlein, J., Wanke, R., Weis, S., Brem, G., and Hermanns, W. 1994. Sensitive detection of human growth hormone mRNA in routinely formalin-fixed, paraffin-embedded transgenic mouse tissues by non-isotopic in situ hybridization. Histochemistry 102:145-152.

19. Erber, W. N., Asbahr, H. D. M., and Phelps, P. N. 1993. In situ hybridization of immunoglobulin light chain messenger RNA on bone marrow trephines using biotinylated probes and the APAAP method. Pathology 25:63-67.

20. Erber, W. N., Willis, J. I., and Hoffman, G. J. 1997. An enhanced immunocytochemical method for staining bone marrow trephine sections. J. Clin. Pathol. 50:389-393.

21. Firrao, G., Carraro, L., Gobbi, E., and Locci, R. 1996. Molecular characterization of a phytoplasma causing phyllody in clover and other herbaceous hosts in northern Italy. Eur. J. Plant Pathol. 102:817-822.

22. Firrao, G., Gobbi, E., and Locci, R. 1993. Use of polymerase chain reaction to produce oligonucleotide probes for mycoplasmalike organisms. Phytopathology 83:602-607.

23. Gibb, K., and Padovan, A. 1994. A DNA extraction method that allows reliable PCR amplification of MLO DNA from "difficult" plant host species. PCR Methods Appl. 4:56-58. 
24. Goodwin, P. H., Xue, B. G., Kuske, C. R., and Sears, M. K. 1994. Amplification of plasmid DNA to detect plant pathogenic mycoplasmalike organisms. Ann. Appl. Biol. 124:27-36.

25. Gundersen, D. E., Lee, I. M., Rehner, S. A., Davis, R. E., and Kingsbury, D. T. 1994. Phylogeny of mycoplasmalike organisms (phytoplasmas): A basis for their classification. J. Bacteriol. 176:5244-5254.

26. Guo, Y. H., Cheng, Z. M., Walla, J. A., and Zhang, Z. 1998. Diagnosis of $\mathrm{X}$-disease phytoplasma in stone fruits by a monoclonal antibody developed directly from a woody plant. J. Environ. Hortic. 16:33-37.

27. Hunyady, B., Krempels, K., Harta, G., and Mezey, E. 1996. Immunohistochemical signal amplification by catalyzed reporter deposition and its application in double immunostaining. J. Histochem. Cytochem. 44:1353-1362.

28. Jiang, Y. P., Chen, T. A., Chiykowski, L. N., and Sinha, R. C. 1989. Production of monoclonal antibodies to peach eastern X-disease agent and their use in disease detection. Can. J. Plant Pathol. 11:325-331.

29. Kirkpatrick, B. C. 1992. Mycoplasma-like organisms-Plant and invertebrate pathogens. Pages 4050-4067 in: The Prokaryotes, 2nd ed., Vol. IV. A. Balows, H. G. Trüper, M. Dworkin, W. Harder, and K.-H. Schleifer, eds. Springer-Verlag, New York.

30. Lee, I. M., Bertaccini, A., Vibio, M., and Gundersen, D. E. 1995. Detection of multiple phytoplasmas in perennial fruit trees with decline symptoms in Italy. Phytopathology 85:728-735.

31. Lee, I. M., Gundersen, D. E., Hammond, R. W., and Davis, R. E. 1994. Use of mycoplasmalike organism (MLO) group-specific oligonucleotide primers for nested-PCR assays to detect mixed-MLO infections in a single host plant. Phytopathology 84:559-566.

32. Lee, I. M., Gundersen-Rindal, D. E., and Bertaccini, A. 1998. Phytoplasma-Ecology and genomic diversity. Phytopathology 88:1359-1366.

33. Lee, I. M., Gundersen-Rindal, D. E., Davis, R. E., and Bartoszyk, I. M. 1998. Revised classification scheme of phytoplasmas based an RFLP analyses of 16s rRNA and ribosomal protein gene sequences. Int. J. Syst. Bacteriol. 48:1153-1169.

34. Lherminier, J., Bonfiglioli, R. G., Daire, X., Symons, R. H., and BoudonPadieu, E. 1999. Oligodeoxynucleotides as probes for in situ hybridization with transmission electron microscopy to specifically localize phytoplasma in plant cells. Mol. Cell. Probes 13:41-47.

35. Lherminier, J., and Boudon-Padieu, E. 1996. In situ detection of grapevine Flavescence Doree phytoplasmas and their infection cycle in experimental and natural hosts. Pages 245-255 in: Histology, Ultrastructure and Molecular Cytology of Plant-Microorganism Interactions. M. Nicole and V. Gianinazzi-Pearson, eds. Kluwer Academic Publishers, Amsterdam.

36. Lherminier, J., Courtois, M., and Caudwell, A. 1994. Determination of the distribution and multiplication sites of Flavescence Doree mycoplasma-like organisms in the host plant Vicia faba by ELISA and immunocytochemistry. Physiol. Mol. Plant Pathol. 45:125-138.

37. Lherminier, J., Prensier, G., Boudon-Padieu, E., and Caudwell, A. 1990. Immunolabeling of grapevine Flavescence Doree MLO in salivary glands of Euscelidius variegatus: A light and electron microscopy study. J. Histochem. Cytochem. 38:79-86.

38. Lherminier, J., Terwisscha Van Scheltinga, T., Boudon-Padieu, E., and Caudwell, A. 1989. Rapid immunofluorescent detection of the grapevine Flavescence Doree mycoplasma-like organism in the salivary glands of the leafhopper Euscelidius variegatus Kbm. J. Phytopathol. 125:353-360.

39. Liefting, L. W., Beever, R. E., Winks, C. J., Pearson, M. N., and Forster, R. L. S. 1997. Planthopper transmission of phormium yellow leaf phytoplasma. Australas. Plant Pathol. 26:148-154.

40. Lorenz, K. H., Schneider, B., Ahrens, U., and Seemüller, E. 1995. Detection of the apple proliferation and pear decline phytoplasmas by PCR amplification of ribosomal and nonribosomal DNA. Phytopathology 85: 771-776.

41. Maixner, M., Ahrens, U., and Seemüller, E. 1995. Detection of the German grapevine yellows (Vergilbungskrankheit) MLO in grapevine, alternative hosts and a vector by a specific PCR procedure. Eur. J. Plant Pa- thol. 101:241-250.

42. Malisano, G., Firrao, G., and Locci, R. 1996. 16S rDNA-derived oligonucleotide probes for the differential diagnosis of plum leptonecrosis and apple proliferation phytoplasmas. Bull. OEPP 26:421-428.

43. Marcone, C., Ragozzino, A., and Seemüller, E. 1996. Association of phytoplasmas with the decline of European hazel in southern Italy. Plant Pathol. 45:857-863.

44. Marzachi, C., Veratti, F., and Bosco, D. 1998. Direct PCR detection of phytoplasmas in experimentally infected insects. Ann. Appl. Biol. 133: 45-54.

45. McCoy, R. E., Cauldwell, A., Chang, C. J., Chen, T. A., Chiykowski, L. N., Cousin, M. T., Dale, J. L., de Leeuw, G. T. N., Golino, D. A., Hackett, K. J., Kirkpatrick, B. C., Marwitz, R., Petzold, H., Sinha, R. C., Sugiura, M., Whitcomb, R. F., Yang, I. L., Zhu, B. M., and Seemüller, E. 1989. Plant diseases associated with mycoplasma-like-organisms. Pages 546640 in: The Mycoplasmas, Vol. V. R. F. Whitcomb and J. G. Tully, eds. Academic Press, New York.

46. McGadey, J. 1970. A tetrazolium method for non-specific alkaline phosphatase. Histochemie 23:180-184.

47. McInnes, J. L., and Symons, R. H. 1989. Enzymatic and chemical techniques for labeling nucleic acids with radioisotopes. Pages 1-31 in: $\mathrm{Nu}-$ cleic Acid Probes. R. H. Symons, ed. CRC Press, Inc., Boca Raton, FL.

48. McInnes, J. L., and Symons, R. H. 1989. Preparation and detection of nonradioactive nucleic acid and oligonucleotide probes. Pages 33-80 in: Nucleic Acid Probes. R. H. Symons, ed. CRC Press, Inc., Boca Raton, FL.

49. Morris, R. E., and Horowitz, D. A. 1984. Cellular enzyme-linked immunospecific assay (CELISA). IV. Inhibition of endogenous cellular alkaline phosphatase activity. J. Immunol. Methods 68:11-17.

50. Namba, S., Kato, S., Iwanami, S., Oyaizu, H., Shiozawa, H., and Tsuchizaki, T. 1993. Detection and differentiation of plant-pathogenic mycoplasmalike organisms using polymerase chain reaction. Phytopathology 83:786-791.

51. Purcell, A. H. 1982. Insect vector relationships with procaryotic plant pathogens. Annu. Rev. Phytopathol. 20:397-417.

52. Raine, J., Forbes, A. R., and Skelton, F. E. 1976. Mycoplasma-like bodies, rickettsia-like bodies and salivary bodies in salivary glands of the leafhopper Macrosteles fascifrons (Homoptera: cicadelidae). Can. Entomol. 108:1009-1019.

53. Schneider, B., Marcone, C., Kampmann, M., Ragozzino, A., Lederer, W., Cousin, M. T., and Seemüller, E. 1997. Characterization and classification of phytoplasmas from wild and cultivated plants by RFLP and sequence analysis of ribosomal DNA. Eur. J. Plant Pathol. 103:675-686.

54. Sinha, R. C., and Chiykowski, L. N. 1986. Detection of mycoplasmalike organisms in leafhopper vectors of aster yellow and peach-X disease by immunosorbent electron microscopy. Can. J. Plant Pathol. 8:387-393.

55. Sinha, R. C., and Paliwal, Y. C. 1970. Localization of a mycoplasma-like organism in tissues of a leafhopper vector carrying clover phyllody agent. Virology 40:665-672.

56. Smart, C. D., Schneider, B., Blomquist, C. L., Guerra, L. J., Harrison, N. A., Ahrens, U., Lorenz, K. H., Seemüller, E., and Kirkpatrick, B. C. 1996. Phytoplasma-specific PCR primers based on sequences of the $16 \mathrm{~S}-23 \mathrm{~S}$ rRNA spacer region. Appl. Environ. Microbiol. 62:2988-2993.

57. Smith, L. M., Fung, S., Hunkapiller, M. W., Hunkapiller, T. J., and Hood, L. E. 1985. The synthesis of oligonucleotides containing an aliphatic amino group at the $5^{\prime}$ terminus: Synthesis of fluorescent DNA primers for use in DNA sequence analysis. Nucleic Acids Res. 13:2399-2412.

58. Vega, F. E., Davis, R. E., Barbosa, P., Dally, E. L., Purcell, A. H., and Lee, I. M. 1993. Detection of a plant pathogen in a nonvector insect species by the polymerase chain reaction. Phytopathology 83:621-624.

59. Zepp, K., Hahn, D., and Zeyer, J. 1997. Evaluation of a 23 S rRNA insertion as target for the analysis of uncultured frankia populations in root nodules of alders by whole cell hybridization. Syst. Appl. Microbiol. 20: 124-132. 